\title{
Globalization impact on the world travel market development
}

\author{
Iryna Mykhailivna Trunina $^{1 *}$, Olena Anatoliivna Sushchenko ${ }^{2}$, Viktoriia Valeriivna \\ Druzhynina $^{1}$ and Olena Leonidivna Zahorianska ${ }^{1}$ \\ ${ }^{1}$ Kremenchuk Mykhailo Ostrohradskyi National University, Pershotravneva Street 20, 39600 \\ Kremenchuk, Ukraine \\ ${ }^{2}$ Simon Kuznets Kharkiv National University of Economics, Nauky Ave 9A, 61000 Kharkiv, Ukraine
}

\begin{abstract}
The paper deals with the research of the theoretical and methodological bases of the world travel market functioning, taking into account the new trends influence on it and gives the characteristic of the forms of these trends. We provide the globalization processes dynamics assessment and their impact on the world travel market development. It enables the determination of the main features of Ukraine's participation at the world travel market and results in the indication of the Ukrainian tourist product development prospects at it. We prove that the development of tourism, as one of the basic branches of national economy, is an important factor of the social development and cultural growth of Ukraine. Tourism is the source of foreign currency income in the state treasury and also the center of new jobs creation. The interest of foreign tourists in our history and culture will grow with the Ukraine tourism development, which will enable our country to preserve its cultural and historical heritage and to be successfully placed at the world travel market. Key words: globalization, tourist activity, world travel market, macroregions, integration, global trends
\end{abstract}

\section{Problem statement}

At the end of XX and the beginning of XXI centuries the processes that got the name of globalization began to manifest more distinctly and dynamically in the development of the world economy. It is these processes that significantly influence the growth of economy, the increase of the country competitiveness at the world markets, the improvement of the welfare of the population. The globalization processes at the travel market are characterized by the change of technologies, the business activity internationalization, the transport infrastructure modernization, the new regulation mechanisms creation.

The objective necessity for the further world travel market development practical bases development and improvement in the current world economy, taking into account the influence of globalization, explains the topicality of this research subject.

\footnotetext{
*Corresponding author: author@email.org
} 


\section{Brief literature review}

The papers of such outstanding scientists as M. Bosovska, J. Nesbitt, O. Plotnikov, M. Ryza, V. Rokoch, V. Kvartalnov, G. Harris, et al. deal with the problems of the development of the world travel market. Such Ukrainian and foreign scientists as O. Bilorus [1], S. Sokolenko [2], D. Lukianenko [3], V. Sokolov [4] contributed a lot into the study of the globalization impact on the world market. However, the problems of the basic aspect's determination of current globalization processes impact on the international tourism development and the international tourism study in the global and regional processes context are insufficiently covered.

\section{Purpose of study}

Consists in the analysis of the international travel market in the context of globalization and the Ukraine efficient integration into the world travel market further prospects determination.

\section{Results}

Nowadays the most world economies develop in close cooperation. This situation is caused by the historical conditions and current relations concerning the big-scale collaboration in the fields of trade, investments, recreation trips and business. These are the direct relations between the enterprises, organizations, the bodies of local self-government, states, economies and their separate industries in their foreign activity. All the mentioned interrelations take place within the framework of such a phenomenon as globalization that essentially influences the economic and social spheres of management.

In the special literature one can come across a lot of definitions of globalization and almost all of them indicate its wide range. Table 1 contains the definitions illustrating the basis of the globalization concept.

Table 1. Globalization in the theoretical approach.

\begin{tabular}{|c|l|c|}
\hline Author & \multicolumn{1}{|c|}{ The definition of "globalization" } & Source \\
\hline 1 & \multicolumn{1}{|c|}{2} & 3 \\
\hline P. Haggett & $\begin{array}{l}\text { a series of events, decisions and reactions taking place in some part of th } \\
\text { farth and significantly influencing the functioning of the economy and th } \\
\text { ociety in the farthest parts of the world; it is a process based on the spatia } \\
\text { ssues and community independently of the location }\end{array}$ & {$[5]$} \\
\hline M. Czerny & $\begin{array}{l}\text { from the point of view of Geographical sciences, it is the change from the } \\
\text { local, regional scale to the global one with the participation of two } \\
\text { necessary interacting factors, i.e. man and the environment }\end{array}$ & {$[6]$} \\
\hline $\begin{array}{c}\text { The European } \\
\text { Commission }\end{array}$ & $\begin{array}{l}\text { process including the final production and markets situated in differen } \\
\text { parts of the world, inseparably interrelated by contracts, commercial and } \\
\text { inancial-technological activity }\end{array}$ & {$[7]$} \\
\hline Z. Bauman & $\begin{array}{l}\text { a process of the acceptance of the global rules and standards and refusal } \\
\text { from the democratic and autonomous policy }\end{array}$ & {$[8]$} \\
\hline $\begin{array}{c}\text { Zakharova M.V. } \\
\text { Kashanina T.V. }\end{array}$ & $\begin{array}{l}\text { Globalization is a multi-social phenomenon; it is a world process that } \\
\text { covers all the spheres of the social life and joins national states into one } \\
\text { common system }\end{array}$ & {$[9,10]$} \\
\hline Shergin S.O. & $\begin{array}{l}\text { the determination of the existent types of local communities, measures and } \\
\text { parameters and also social relations with other communities within the } \\
\text { global international space and the reconstruction of the model of their } \\
\text { interrelation with the external world }\end{array}$ & {$[11]$} \\
\hline
\end{tabular}




\begin{tabular}{|c|l|l|l|}
\hline Kravchuk M. & $\begin{array}{l}\text { the formation of the integrated general information space by means of the } \\
\text { development of information-computer technologies, which provides a } \\
\text { powerful impulse to the acceleration of the process of borrowing cultural } \\
\text { and institutional acquisitions, and the creation of certain universalization } \\
\text { of the forms of social life on this basis. This expansion results in ruining } \\
\text { of the traditional sociocultural forms and institutions. }\end{array}$ & [12] \\
\hline Kosolapov N.A. & $\begin{array}{l}\text { the intensification of the crisis phenomena and weakening of the role of } \\
\text { the national state the tendency to the unification of the power, the global } \\
\text { expansion of the consumption means, the solution to the local problems in } \\
\text { the context of the global community, the flexible and multi-center } \\
\text { character of the international relations. }\end{array}$ & [13] \\
\hline $\begin{array}{c}\text { H. Borne, A. } \\
\text { Doliński }\end{array}$ & $\begin{array}{l}\text { New directions and tendencies in the international tourism due to } \\
\text { geopolitical changes causing the occurrence of the phenomenon of the } \\
\text { international mass tourism that got the name of "technified tourism" }\end{array}$ & [14] \\
\hline
\end{tabular}

Source: Authors.

Analyzing Table 1 and the literature in the subject, it is possible to say that globalization is the process of the world economic, political and cultural mutual drawing together and creation of interrelations.

Unfortunately, there are definitions that object to great globalization as this phenomenon results in the loss of the state identity both economic and social dependence and even the increase of the level of unemployment and environment pollution [15]. In spite of different approaches to the globalization phenomenon, in most definitions both economy and society are the important factors underlying the basis of the globalization of the world economy. Thereby, the analysis of the main directions of globalization makes it possible to determine the human life main parts influenced by it most of all: business activity, industry, the development of new technologies, tourism, culture and recreation, social attitude, ecology, social-economic responsibility $[16,17]$.

Taking into account the above mentioned points, it should be noted that globalization equally concerns both economy and society [18]. The interrelation between globalization and tourism is worth thinking about as it is an important element of the social activity and, at the same time, one of the main branches of economy. From the point of view of tourism, globalization is defined as a process that unites people all over the world, minimizing the transport cost, leveling the boundaries, cultural and social barriers, facilitating the access to new fields of knowledge and work. The consequences of the globalization in tourism influence the following factors: unlimited access to information; the development and constant modernization of the means of transport, free markets and foreign trade related to them, the expansion of the hotel networks in the international markets, considerable demand for travel services, international competition.

Many specialists state that globalization positively influences the economy of tourism and tourism itself. Due to these processes the current world touristic sphere rapidly progresses. Its development promotes active economic growth of many countries of the world. However, the tourism development world trends essentially influence the tourism branch development of a particular country economy. Nowadays tourism has become an independent branch of economy. It makes almost $6 \%$ of the world gross national product, $5 \%$ of all taxes and $7 \%$ of the world investments. The tourism industry development promotes the increase of the budget income, the new jobs creation, the infrastructure development, the new tourist objects construction, the intensification of the protection and reconstruction of the existing historicalcultural monuments. In many countries the tourism has become an important source of budget and belongs to the most promising branches of the national economy. The expansion of the recreation-tourism industry and the growth of its influence on the economic development are among the world economy development priority directions. 
Considerable territory irregularity is typical for the current international tourism. In the most general form it reflects different social-economic levels of the world' countries: economically developed countries obtain $57 \%$ of the profit, developing countries get $30 \%$, the countries with transient economy $-13 \%$. Based on such regional structure of tourism income and profit it is possible to distinguish between five tourist macroregions of the world:

1. European region (the countries of West, North, South, Central, East Europe, and also the countries of the East Mediterranean - Israel, Cyprus, Turkey).

2. American region (the countries of North, South, Central America, the island countries and the territories of the Caribbean basin).

3. Asian-Pacific region (the countries of East and South-East Asia, Australia and Oceania).

4. African region (the countries of Africa except Egypt and Libya).

5. Middle East region (the countries of West and South-West Asia, Egypt, Libya).

The progressive dynamics of development is typical of all the macroregions but the rate is different and the number of tourist arrivals is also different. The Travel \&Tourism world organization makes annual rating of the world' countries as to the tourist arrivals and the tourism income and, based on these data, forms the index of competitiveness (IGC) of all world countries in the travel industry (Table 2).

Table 2. Analysis of the competitiveness index (IGC) of tourist macro-regions of the world in 20152016, (formed according to the data 19).

\begin{tabular}{|c|c|c|c|c|c|c|c|c|}
\hline \multirow[b]{2}{*}{ No } & \multirow[b]{2}{*}{$\begin{array}{c}\text { Touristic } \\
\text { macroregions } \\
\text { of the world }\end{array}$} & \multirow[b]{2}{*}{$\begin{array}{c}\text { Number of } \\
\text { countries }\end{array}$} & \multirow[b]{2}{*}{$\begin{array}{l}\text { Name of the } \\
\text { country }\end{array}$} & \multicolumn{2}{|c|}{2015} & \multicolumn{2}{|c|}{2016} & \multirow[b]{2}{*}{$\begin{array}{c}\text { Share of } \\
\text { tourist } \\
\text { arrivals, \% }\end{array}$} \\
\hline & & & & IGC max & IGC min & IGC max & IGC min & \\
\hline \multirow[b]{2}{*}{1} & \multirow[b]{2}{*}{ European } & \multirow[b]{2}{*}{41} & Switzerland & 5.76 & - & 5.81 & - & \multirow[b]{2}{*}{58} \\
\hline & & & \begin{tabular}{|l} 
Bosnia and \\
Herzegovina
\end{tabular} & - & 3.71 & - & 3.8 & \\
\hline \multirow{2}{*}{2} & \multirow{2}{*}{ Asian-Pacific } & \multirow{2}{*}{27} & Singapore & 5.68 & - & 5.72 & - & \multirow{2}{*}{19} \\
\hline & & & Kirghizia & - & 3.87 & - & 3.75 & \\
\hline \multirow{2}{*}{3} & \multirow{2}{*}{ American } & \multirow{2}{*}{21} & USA & 5.61 & - & 5.7 & - & \multirow{2}{*}{17} \\
\hline & & & Venezuela & - & 3.3 & - & 3.27 & \\
\hline \multirow{2}{*}{4} & \multirow{2}{*}{ African } & \multirow{2}{*}{34} & Mauritius & 4.43 & - & 3.73 & - & \multirow{2}{*}{4} \\
\hline & & & Mauritania & - & 3.03 & - & 2.94 & \\
\hline \multirow{3}{*}{5} & \multirow{2}{*}{ Middle East } & \multirow{2}{*}{14} & UAE & 5.24 & - & 5.26 & - & \multirow{2}{*}{2} \\
\hline & & & Yemen & - & 2.72 & - & 2.74 & \\
\hline & Total: & 137 & - & - & - & - & - & 100 \\
\hline
\end{tabular}

Source: Authors.

Analyzing the data in Table 2 one can come to the conclusion that the biggest share $(58 \%)$ of tourist arrivals belongs to Europe. It is due to the availability of all the types of recreation facilities, steady economic and political situation in this macroregion, the presence of the developed infrastructure and profitable geographic location. However, the recreation in Europe is more expensive than in other macroregions [20].

Asian-Pacific macroregion is the second; the share of its tourist arrivals is $19 \%$. It is explained by the presence of unique and exotic types of the recreation resources, the high level of service and lower prices than in Europe or America. However, unsteady political situation, frequent natural disasters such as earthquakes, tsunami, floods negatively influence this macroregion development. Singapore, being the leader in this group, took the necessary measures related to the international openness to guarantee the safe arrival of international tourists and the quality of its air transport infrastructure is high. The country invested more funds into sightseeing, the development of entertainment and games, and is at the top of the entertainment rating looked for online. Also, the country should put more efforts into 
environmental sustainability especially because of floods stress and the damage of the coastal ecosystems.

American macroregion is the third. A somewhat lower share of tourist arrivals in it can be explained not by the decrease of the tourist attraction of America but by the rapid tempo of the travel industry development in other macroregions. This region is characterized by the availability of most types of the recreation resources, the developed infrastructure. However, the unsteady political situation in the countries of South America, natural disasters in the USA (hurricanes, floods) cause the decrease of the tourist arrivals share. The USA is the top country in American region and the third one in the general rating. With many natural objects of the World Heritage the US occupies the third position in the rating of the natural resources, which also attracts tourists due to cultural, entertaining and sport sites. It is supplemented with a highly competitive business environment and several bilateral air traffic agreements supported by the infrastructure of the air transport of the country. However, the visa requirements are serious, which restricts the growth of tourist arrivals.

The last but one position is occupied by African macroregion, the cheapest place of recreation in the world with rich natural recreation resources, which promotes the increase of the tourist arrivals number. The insufficiently developed infrastructure and the low level of travel services negatively influence the development of the tourism industry. Besides, the availability of political problems and the irregular development of different parts of the continent are obstacles to increase of the tourist flows amount.

Middle East macroregion is characterized by the lowest share of tourist arrivals, which is explained by the unsteady political situation in the region, the absence of the developed tourist infrastructure.

However, a long tourist season, the presence of rich recreation resources, the proximity of developed European states positively influence the tourism development in the region and make a considerable share in its tourism-recreation potential. The United Arab Emirates (UAE) are the leaders in the region and occupy the 16th position in the general rating as they accepted more than $10 \mathrm{mln}$ tourists in 2016. While there are no rich natural resources in the UAE, the country created the unique environment to attract tourists for business and recreation.

Analysis of the world travel market makes it possible to come to conclusion that the international tourism develops in close correlation with other spheres of international life and responds to the general economic state of the market and political situation by the increase or decrease of the growth rate.

It explains the irregularity of the international tourism development in different periods and its special features in different regions. Under these conditions it is especially important to develop the directions of the competitiveness improvement of such national travel markets, in particular, Ukrainian one, that should take into account the modern tendencies of world economy development and the special features of the country tourism-recreation potential.

Geographically, Ukraine belongs to European macroregion and has the following competitiveness indices, based on data from the world tourism organization (Travel\&Tourism): in 2015 IGC was 4.03, which is the 79th position in the general rating; in 2016 IGC was 4.00 , which is the 85 th position in the general rating. Thus, it is obvious that the position of Ukraine at the world travel market deteriorated in comparison with 2013, one can also state that the tourism potential in Ukraine is used insufficiently; the results by the subindex "Human, cultural and natural resources" are especially low [19, 21] (Table 3).

From 2012 till 2013 the number of Ukrainian tourists who travelled abroad increased almost by 1.5 times. However, from 2013 till 2016 it decreased almost by 9 times. The number of the served tourists from 2012 till 2013 increased more than by 20 times, which is an extremely high index. From 2013 till 2016 it decreased by 16.5 times [20, 21]. 
Table 3. Rating of the world' countries according to the Travel \& Tourism competitiveness index in 2015-2016 in comparison with 2013, (formed according to the data 20,21)

\begin{tabular}{|c|c|c|c|c|c|c|c|c|c|}
\hline \multirow[t]{2}{*}{ No. } & \multirow[t]{2}{*}{ Country } & \multicolumn{2}{|c|}{ IGC 2013} & \multicolumn{3}{|c|}{ IGC 2015} & \multicolumn{3}{|c|}{ IGC 2016} \\
\hline & & rating & points & rating & points & $\begin{array}{c}\Delta 2015 / \\
2013\end{array}$ & rating & points & $\begin{array}{c}\Delta 2016 / \\
2013\end{array}$ \\
\hline 1 & Switzerland & 1 & 5.66 & 1 & 5.76 & 0 & 1 & 5.81 & 0 \\
\hline 2 & Singapore & 10 & 5.23 & 2 & 5.68 & $\uparrow 8$ & 2 & 5.72 & $\uparrow 8$ \\
\hline 3 & USA & 6 & 5.32 & 3 & 5.61 & $\uparrow 3$ & 3 & 5.7 & $\uparrow 3$ \\
\hline 4 & Netherlands & 13 & 5.14 & 5 & 5.5 & $\uparrow 8$ & 4 & 5.57 & $\uparrow 9$ \\
\hline 5 & Germany & 2 & 5.39 & 4 & 5.53 & $\downarrow 2$ & 5 & 5.57 & $\downarrow 3$ \\
\hline 6 & Sweden & 9 & 5.54 & 9 & 5.43 & 0 & 6 & 5.53 & $\downarrow 3$ \\
\hline 7 & Great Britain & 5 & 5.38 & 10 & 5.43 & $\downarrow 5$ & 7 & 5.49 & $\downarrow^{2}$ \\
\hline 8 & Japan & 14 & 5.13 & 6 & 5.47 & $\uparrow 8$ & 8 & 5.48 & $\uparrow 6$ \\
\hline 9 & Finland & 17 & 5.1 & 8 & 5.45 & $\uparrow 9$ & 10 & 5.44 & $\uparrow 7$ \\
\hline 10 & Norway & 22 & 4.95 & 11 & 5.41 & $\uparrow 11$ & 11 & 5.44 & १11 \\
\hline 11 & UAE & 28 & 4.86 & 17 & 5.24 & $\uparrow 11$ & 16 & 5.26 & $\uparrow 12$ \\
\hline 12 & Spain & 4 & 5.38 & 33 & 4.59 & $\downarrow 29$ & 32 & 4.68 & $\downarrow 28$ \\
\hline 13 & Ukraine & 76 & 3.98 & 79 & 4.03 & $\downarrow 3$ & 85 & 4 & $\downarrow 9$ \\
\hline 14 & Yemen & 133 & 2.96 & 138 & 2.73 & $\downarrow 5$ & 138 & 2.74 & $\downarrow 5$ \\
\hline
\end{tabular}

Source: Authors.

Fig.1 allows the analysis of the state of Ukraine at the world travel market in more detail. Switzerland was chosen the leader as this country has been occupying the first position in the world competitiveness rating for many years.

Analyzing the information above, one can state that Ukraine's indices of the travel services development are below the average among the countries of European macroregion. It especially concerns the macroeconomic indices of the state development; the weak development of the financial market that hampers the investment into the travel industry and the innovation development

Ukraine has all the conditions for the intensive development of the incoming and outcoming tourism: the special features of the geographic location and relief, a favorable climate, the wealth of the natural, historical-cultural and tourism-recreation potentials. Unfortunately, Ukraine looks rather modest against the background of the world tourism that advances with extreme rapidity.

Now Ukrainian citizens are kind of investors of the foreign countries, which is one of the most painful problems of the whole tourism industry. There is no doubt that the causes of this state are to be looked for in the complicated social-economic situation in the country, in the unadjusted mechanisms of stimulation in the travel industry, in the absence of the efficient strategy of the development of this industry both at the national and regional level, in the 
inaccessibility of financing sources, in the taxation system imperfection, in the innovation sphere insufficient development.

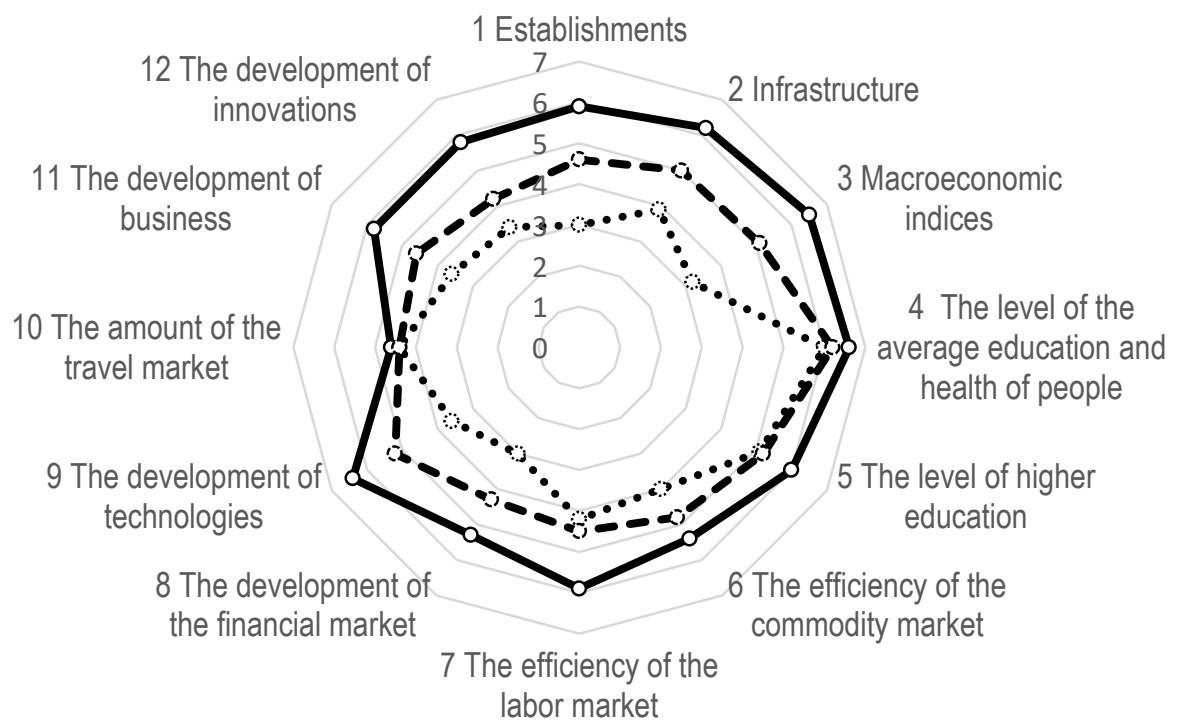

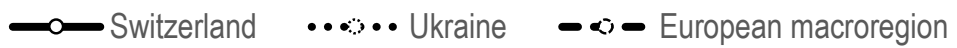

Fig. 1. The state of Ukraine at the European travel market, (formed according to the data 20, 21).

Source: Authors.

Obviously, Ukraine is extremely rich in almost all the types of tourism resources and can be rather attractive for foreign investors. However, unfortunately, the country tourist infrastructure is insufficiently developed for it, so, first of all, it is necessary to completely modernize all the hotels and restaurant enterprises, and roads. Of course, such measures require considerable funds that our country is not able to provide, especially under the conditions of economic crisis.

There is no complete examination of the whole tourism industry of Ukraine with the profound information, statistic data, analytical conclusions and remarks.

Despite the fact that nowadays there are general principles of the international tourism organization, it's functioning and development, every country that pays special attention to this branch of economy applies its own models of tourism. It results from different reasons based on historical, geographical, climatic, economic and social specific features of each country or region. Every country, that develops the tourism industry, tries to completely use its national resources aiming at obtaining considerable currency income to the budget.

\section{Conclusions}

Among the current tendencies of the world market development on the whole and the travel market in particular, the globalization processes deserve special attention. The present paper contains the theoretical substantiation of these processes. They are characterized by the following features: the change of technologies, the modernization of the transport infrastructure, the business activity internationalization, the international tourism regulation 
mechanism creation. With the development of these processes one can observe active economic growth of many countries of the world, in particular, due to the tourist flows amount increase.

Taking into account the performed analysis of the main world macroregions development, we revealed their development irregularity by means of the travel industry competitiveness index calculation. We have found out that the international tourism rapidly responses to the changes of the general economic state of the market and political situation and under such conditions the assessment of Ukrainian travel market competitiveness, taking into account the world economy development trends and the country tourism-recreation potential features, is of special significance. The results of this assessment certify that Ukraine demonstrates considerable lag in the average indices of European macroregion development as to the country development macroeconomic indices, the financial market development indices, which hampers the investment into the tourism industry and the innovations development.

Taking into account the above results of the research, it is possible to formulate the main strategic imperatives for the Ukrainian tourism industry development both at the national and world level. Firstly, the intensive information and Ukraine tourism potentials advertising by means of the circulation of the whole tourism industry complete examinations with the profound information, statistic data, analytical conclusions and remarks. Secondly, the travel activity stimulation mechanisms creation of both incoming and outcoming tourists via the tourist infrastructure modernization, in particular, hotels and catering enterprises. Thirdly, the innovations in tourism local programs development working out, their efficiency assessment, the innovation financial-credit support substantiation, the travel enterprises innovation policy strategies and tactics determination with the further involvement of highly qualified guides, hotel business employees, marketing specialists, managers and other specialists into the travel market.

The formed database can be used in the further research to create the economicmathematical models of the Ukrainian tourism industry development taking into account its regions development potential.

\section{References}

1. O.H. Bilorus, Ekonomichna systema hlobalizmu [The economic system of globalism]. KNEU, Kyiv, 360 (2003)

2. S.I. Sokolenko, Hlobalizatsiia i ekonomika Ukrainy [Globalization and the economy of Ukraine]. Kyiv, 568 (2009)

3. D.H. Luk'ianenko, Hlobalna ekonomichna intehratsiia [Global Economic Integration]. Kyiv, 220 (2008)

4. V. Sokolov, Konturyi buduschego mira: natsii, regionyi, transnatsionalnyie obschnosti [The contours of the future world: nations, regions, transnational communities]. Moscow University Bulletin, 3, 23-67 (2004)

5. P. Haggett, Geography. A global synthesis. Pearson Education Limited, Prentice Hall, Harlow, UK (2001)

6. M. Czerny, Globalizacja a rozwój. Wybrane zagadnienia geografii społecznogospodarczej świata [Globalization and development. Selected issues of socio-economic geography of the world] (2005)

7. P. Dominiak, J. Wasilczuk, N. Daszkiewicz, Small and medium-sized enterprises in the face of internationalization and integration of European economies. Examples of Italy, France, Poland and the Czech Republic, Scientific Publishing Group, 7, $42-53$ (2005) 
8. Z. Bauman, Globalizacja. Państwowy Instytut Wydawniczy, Warszawa, 67-83 (2000)

9. M.V. Zaharova, Sravnitel'noe pravovedenie: voprosy teorii i praktiki [Comparative Law: Theory and Practice]. Moskow: Prospekt, 160 (2013)

10. T.V. Kashanyna, Struktura prava [Right structure]. Moskow: Prospekt, 584 (2013)

11. S.O. Sherhin, Kontseptualno-prakselogichni aspekty globalizatsiinogo rozvytku [Conceptual-praxeological aspects of globalization development]. Globalizatsiia $i$ suchasnyi mizhnarodnyi protsess - Globalization and modern international process, 104-105 (2009)

12. M. Kravchuk, Kontseptualna evoliutsiia teorii globalizatsii [The conceptual evolution of the globalization theories]. Politychnyi menedzhment-Political management, 2, 122-137 (2009)

13. N.A. Kosolapov, Mezhdunarodno-politicheskaia organizatsiia globaliziruiuzhegosia mira [The international political organization of the globalized world: models for a medium-term prospect]. Obshchestvennye nauki i sovremennost - Social sciences and modernity, 6, 141-143 (2001)

14. H. Borne, A. Doliński, Organizacja turystyki. WSiP, Warszawa, 23-26 (1998)

15. V. Druzhynina, G. Likhonosova, Strategic imperatives ensuring population welfare under transformation exclusion conditions. Baltic Journal of Economic Studies, 3(5), 135-146 (2017)

16. I.M. Trunina, O.A. Sushchenko, G.S. Likhonosova, The territory recreation ensuring management system design. Economic Theory and Practice, 1, 635-647 (2017)

17. I.M. Trunina, O.A. Sushchenko, Creation of innovation clusters as a line of enterprise competitiveness improvement in the field of foreign economic activity. Actual Problems of the Economy, 3 (177), 191-198 (2016)

18. V. Druzhynina, G. Likhonosova, G. Lutsenko, Assessment welfare of the population in the synergetic system of socio-economic exclusion. Marketing and Management of Innovations, 2, 54-68 (2018)

19. A.Y. Dubeniuk, Otsinra konkurentospromozhnosti turystychnoi galuzi Ukrainy [The assessment of the competitiveness of the tourist industry of Ukraine]. Problemy razvitiia vneshneekonomicheskih sviazei i privlechenie inostrannyh investitsii: regionalnyi aspect - The problems of the development of the foreign economic relations and attraction of foreign investments: regional aspekt, Donetsk: DonNU, 7, 754-761 (2007)

20. The Travel \& Tourism Competitiveness Report [online], Available at: http://www3.weforum.org/docs/WEF_TT_Competitiveness_Report_2013.pdf. (2013)

21. The Travel \& Tourism Competitiveness Report [online], Available at: http://www3.weforum.org/docs/GCR20162017/05FullReport/TheGlobalCompetitivene ssReport2016-2017_FINAL.pdf (2017) 